\title{
A Method for Production and Characterization of Biodiesel from Green Micro Algae
}

\author{
${ }^{1}$ Indhumathi P, ${ }^{2}$ Syed Shabudeen* P.S, ${ }^{3}$ Shoba U.S \\ Department of Chemistry, Kumaraguru College of Technology, \\ Coimbatore ,Tamilnadu, India
}

\begin{abstract}
Biofuels are one of those renewable fuel sources developed to fuel the transportation sector to replace conventional petroleum based fuels. Due to widespread research and development programs from last two decades, significant progress has been made in the field of biofuels. The first and second generation biofuels are produced from various food crops and plant seed oils. Algae has been identified as a the potential source to produce biofuels, which can replace transportation fuels derived from fossil energy sources due to various advantages than the previous two generation feed stocks. The ability to produce high amounts of oil, efficiency in harvesting solar energy, adaptability to different climatic conditions and capability to produce valuable byproducts makes algae as a potential source for renewable energy source. In the present work the key concentration is directed towards producing renewable biofuels from algal biomass by transesterfication process. Its Characterization study reveals that algal based biodiesel is an alternative source of diesel.
\end{abstract}

Keywords: Algae, Lipid, Biodiesel, Fuel properties

\section{Introduction}

Biodiesel is the name given to fuel for Diesel engines created by the chemical conversion of animal fats or vegetable oils. Pure vegetable oil works well as a fuel for Diesel engines itself, as Rudolf Diesel demonstrated in his engine at the 1900 world's fair with peanut oil as the fuel.

The United State Fueling stations make biodiesel readily available to consumers across Europe and increasingly in the USA and Canada. This is an indication that biodiesel can operates in compression ignition engines like petroleum diesel without requiring no essential engine modifications [1-3]. Moreover it can maintain the payload capacity and range of conventional diesel unlike fossil diesel, pure biodiesel is bio-degradable, nontoxic and essentially free of sulphur and aromatics [4-6].

A growing number of transport fleets use it as an additive in their fuel. Biodiesel is being used in both public and private fleet vehicles due to environmentally friendly and the facts that it offers a reduction in some emissions without requiring any modifications to the vehicle of biodiesel [1]. It is worth of mentioning that the production of this alternative energy source (biodiesel), which is a variety of ester-based oxygenated fuels, can be produced from different feedstock, such as vegetable oil, animal fats and non edible oils [7-11]. Hence, the production of biodiesel is sensitive to feedstock; care must therefore take in selecting the feed stock for the production of biofuels.

The advantages of biodiesel as perfect alternative energy sources, emission of NOx is one of the setbacks of biodiesel. The temperature within the cylinders of a vehicle fuelled with

\footnotetext{
Corresponding author: Dr.P.S.Syed Shabudeen,

Professor \& head, Department of Chemistry,
}

Kumaraguru College of Technology, 
biodiesel would increase due to the enhanced combustion as a result of high oxygen content of biodiesel. This increase in temperature stimulates the production of NOx from the reaction with nitrogen in the air, which results in a small increase in NOx emission compared to those produced from conventional diesel fuel [12]. Aside from the formation of NOx by the engine powered with biodiesel, the chemical contents of biodiesel is also a fatty acid methyl ester when the alcohol used during transesterification is methanol or fatty acid ethyl ester in case of ethanol. These ester molecules are susceptible to hydrolytic and oxidization reactions resulting in the formation of polymers. This makes the biodiesel unstable on storage and hence cannot sit on the shelf for long time as it develops mould when it gets old [13]. Exploring the means of producing biodiesel that will compete well with the existing petroleum diesel is of much interest in the recent biodiesel research, especially for those methods concentrating on minimizing the raw material cost. Biodiesel as alternative energy source can be produced from different sources.

This work involves the study of biodiesel production from green micro algae. The choice of green micro algae as a feedstock for the production of biodiesel is also favoured by the abundantly available in all areas. Hence, Production of biodiesel from algae oil will lead to proper utilization of vegetable oils and it also includes characterization of produced biodiesel.

\section{Materials and Methods}

\subsection{Algal Samples and Oil Extraction}

The algal samples collected and analyzed were identified as green algae-chlorella vulgaris, dried algal biomass $(5 \mathrm{~g})$ was taken in solvent mixture $(100 \mathrm{ml})$ of acetone and the content were refluxed for $4 \mathrm{hrs}$. After the extraction, the contents were cooled and filtered (or centrifuged) to separate the biomass and washed the biomass with $25 \mathrm{ml}$ of acetone twice to extract the residual lipids present in the biomass. The extracts were pooled and taken in a separating funnel and washed with $1 \%$ aqueous sodium chloride solution $(50 \mathrm{ml})$ twice. The solvent were removed by using rota-evaporator under vacuum to get the algal oil. The weight of algal oil was taken to determine the oil content in biomass. If the biomass is available in smaller quantities, the content may be reduced accordingly.

\subsubsection{Alkali Catalyzed Transesterification}

$50 \mathrm{ml}$ of oil was measured and poured into a $150 \mathrm{ml}$ conical flask and heated to a temperature of $45^{\circ} \mathrm{C}$ using a water bath. A solution of sodium methoxide was prepared in a $250 \mathrm{ml}$ beaker using $0.25 \mathrm{~g}$ of $\mathrm{NaOH}$ pellet and $10.5 \mathrm{mls}$ of anhydrous methanol. The solution was properly stirred until the $\mathrm{NaOH}$ pellet was completely dissolved in it. The sodium methoxide solution was then poured into the warm oil and stirred vigorously for 90minutes using a magnetic stirrer and the mixture was left to settle for 24 hours in a separating funnel. After settling, the upper layer which was biodiesel was decanted into a separate beaker while the lower layer which comprises of glycerol and soap was collected from the bottom of the funnel. The quantity of biodiesel collected was measured and recorded.

\subsubsection{Washing and Drying}

Biodiesel must be washed to remove any remaining methanol, glycerin, catalyst, soaps and other impurities. Water used is warmed to about $45^{\circ} \mathrm{C}$ and is passed through the esters to allow soluble material, excess catalyst and other impurities to stick to the water and be settled to the bottom of the vessel. The water is removed from the vessel periodically until the wash water drained out is clear or the $\mathrm{pH}$ of the biodiesel becomes relatively neutral. 
The biodiesel washing sometimes leaves the biodiesel looking a bit cloudy. This means there's still a little water in it. It was heated slowly to $100^{\circ} \mathrm{C}$ and held there until all moisture present was evaporated.

\subsection{Physical and Chemical Characterization of the Biodiesel}

The production of biodiesel from green micro algae (Chlorella vulgaris), and its characterization various anlysis such as $\mathrm{pH}$, Specific gravity Density, Flash point, Fire point, Cloud point, Pour point, Viscosity, Cetane number, Acid value, free fatty acid value, Saponification value, Calorific value, moisture ash content, Carbon residue, $\mathrm{Na}$ and $\mathrm{K}$, Water sedimendation and Copper corrosion test.

\subsubsection{Determination of Acid Value/Free Fatty Acid (FFA)}

$2 \mathrm{~g}$ of the oil was measured and poured in a beaker. A neutral solvent (a mixture of petroleum ether and ethanol) was prepared and $50 \mathrm{ml}$ of it was taken and poured into the beaker containing the oil sample. The mixture was stirred vigorously for 30minutes. $0.56 \mathrm{~g}$ of potassium hydroxide $(\mathrm{KOH})$ pellet was measured and placed in a separate beaker and $0.1 \mathrm{M}$ $\mathrm{KOH}$ was prepared, 3drops of phenolphthalein indicator was added to the sample and was titrated against $0.1 \mathrm{M} \mathrm{KOH}$ till the color change observed turned pink and persisted for 15 minutes.

$$
\mathrm{AV}=\frac{56.1 \times A x N}{\text { Woil }}
$$

Where; V= volume of standard alkali used;

$\mathrm{N}=$ normality of standard alkali used;

Woil $=$ weight of oil used

$\mathrm{FFA}=A V / 2$

\subsubsection{Determination of Saponification Value}

The alcoholic $\mathrm{KOH}$ was freshly prepared by dissolving $\mathrm{KOH}$ pellet in ethanol. $2 \mathrm{~g}$ of oil was measured and poured into a conical flask. $25 \mathrm{ml}$ of the alcoholic $\mathrm{KOH}$ was added to it, a blank was used. The sample was well covered and placed in a steam water bath for 30minutes shaking it periodically, $1 \mathrm{ml}$ of phenolphthalein was added to the mixture and titrated against $0.5 \mathrm{M} \mathrm{HCl}$ to get the end point.

$\mathrm{SV}=\frac{56.1 \times B-A x N}{\text { Woil }}$

Where; $\mathrm{B}=$ volume of standard ethanol potassium hydroxide used in blank titration;

$\mathrm{A}=$ volume of standard ethanol potassium hydroxide used in titration with the oil; $\mathrm{N}=$ normality of standard acid; Woil= weight of oil used. 


\subsubsection{Determination of Moisture Content}

In other to determine the moisture content in the oil (\%), $48.15 \mathrm{~g}$ of oil was weighed in a moisture pan, the weight of the pan and oil was taken and was put inside an oven for 3hours at a temperature of $450^{\circ} \mathrm{C}$. After every 1hour, the sample was cooled and weighed until the weight before and after was approximately equal.

\subsubsection{Determination of Specific Gravity/Density (ASTM D1298) by Hydrometer Method}

This procedure is used to measure of specific gravity of the biodiesels. A clean dry empty $50 \mathrm{ml}$ density bottle is to be weighed and the mass recorded as $\mathrm{M}$, it is then filled up with distilled water and subsequently with the samples. The mass of the bottle and water is taken and recorded as M1 and that of biodiesel as M2 respectively hence, the specific gravity is evaluated. This procedure is used to determine the specific gravity of the sample.

\subsubsection{Determination of Flash Point: ASTM D 93}

A sample of the biodiesel is heated in a close vessel and ignited. When the sample burns, the temperature is recorded, the pensky-martens cup tester measures the lowest temperature at which application of the test flame causes the vapor above the sample to ignite. The biodiesel is placed in a cup in such quantity as to just touch the prescribed mark on the interior of the cup. The cover is then fitted onto the position on the cup and Bunsen burner is used to supply heat to the apparatus at a rate of about $5^{\circ} \mathrm{C}$ per minute. During heating, the oil is constantly stirred. As the oil approaches its flashing, the injector burner is lighted and injected into the oil container after every 12 second intervals until a distinct flash is observed within the container. The temperature at which the flash occurred is then recorded, it is repeated three times and the average taken.

\subsubsection{Determination of Cloud Point and Pour Point (ASTM D 2500,ASTM D 97))}

A sample of the biodiesel is placed in a test jar to a mark and then placed inside a cooling bath. The temperature at the bottom of the test jar that is the temperature at which the biodiesel starts to form cloud is taken as the cloud point.

A sample of the biodiesel is kept in the freezer to about $500^{\circ} \mathrm{C}$ then placed in a heating mantle to melt. The temperature at the bottom of the test jar that is the temperature at which the biodiesel starts to pour is taken as the pour point.

\subsubsection{Determination of Kinematic Viscosity (ASTM D 445)}

A viscometer is inserted into a water bath with a set temperature and left for 30minutes. The sample is added to the viscometer and allowed to remain in the bath as long as it reaches the test thermometer. The sample is allowed to flow freely and the time required for the meniscus to pass from the first to the second timing mark is taken using a stop watch. The procedure is repeated a number of times and the average value are taken which is then multiplied with the viscometer calibration to give the kinematic viscosity.

\subsubsection{Cetane Number (ASTM D 613)}

Cetane Number is a measure of the fuel's ignition delay. Higher cetane numbers indicate shorter times between the injection of the fuel and its ignition. Higher numbers have been associated with reduced engine roughness and with lower starting temperatures for engines. 


\subsubsection{Determination of Distillation Characteristics (ASTM D 86)}

The distillation characteristics were studied using distillation apparatus (Model PMD 100) in accordance to the procedure in ASTM D $86.100 \mathrm{ml}$ of the biodiesel was charged into the distillation flask. A thermometer provided with a snug-fitting cork was tightly fitted into the neck of the distillation flask. The flask was then fixed tightly into the condenser tube by raising and adjusting the flask support board of a calibrated distillation batch unit. Systematic observations and recordings of temperature readings at $5 \mathrm{mls}, 10 \mathrm{mls}, 20 \mathrm{mls}, 30 \mathrm{mls}, 40 \mathrm{mls}$, $50 \mathrm{mls}, 60 \mathrm{mls}, 70 \mathrm{mls}, 80 \mathrm{mls}$, and $90 \mathrm{mls}$ respectively, and volumes of condensate were taken and recorded.

\subsubsection{Determination of Bottom Water and Sediment (ASTM D 2709)}

The water and sediment test was determined according to ASTM D 2709, 50mls of the biodiesel and $50 \mathrm{ml}$ of toluene were mixed in a $100 \mathrm{ml}$ centrifuge tube with the tube tip having graduation of $0.01 \mathrm{ml}$ over the range of 0 to $0.2 \mathrm{ml}$, the centrifuge tube was shaken so that an even distribution of the mixture is observed. The tube was placed in a trunnion cup inside an oil test centrifuge in such a way that the tubes are placed opposite each other to establish a balance in the centrifuge. The centrifuge is then closed and timed for 30 minutes; the samples are then whirled for agitation at a speed of $1800 \mathrm{rpm}$ to ensure homogeneity. The combined water and sediment at the bottom of the tube was reported to the nearest $0.005 \mathrm{ml}$.

\subsection{Molecular Weight Determination}

According to [sathasiva, (1996)], the saponification and acid value of micro algal oil were determined. The molecular weight of the oil was calculated as [Xu et .al.,2006]

$\mathrm{MW}=\frac{168300}{S V-A V}$

Where MW-molecular weight of oil

SV-Saponification value of oil

$\mathrm{AV}$ - acid value of oil

\subsection{Spectral Analysis of Biodiesel}

The petro diesel/biodiesel blends were analyzed using a Evaluation 201 spectrophotometer. The soft-ware Lambda 10 (UV Win Lab) served as an interface between the computer and the spectrophotometer. The samples were placed in a $0.5 \mathrm{~cm}$ wide square quartz cell. A tungsten lamp was employed for the analysis in the visible region and a deuterium lamp was used for the UV region. The analysis of the samples was performed at a temperature of $25^{\circ} \mathrm{C}$. The spectra were collected over the range from $200-1100 \mathrm{~nm}$, and 20 scans were performed for each sample, with a resolution of $2 \mathrm{~nm}$.

Liquids are the easiest to study by IR. A pure sample of the liquid (1-2 drops) may be placed between two disks of pure $\mathrm{NaCl}$ or $\mathrm{KBr}$ and the resulting 'sandwich' placed directly in the sample holder of the spectrometer. Excellent spectra can be obtained in a matter of a few minutes with minimum expense.

Analysis of algal biodiesel was performed through a GC-MS (Perkin-Elmer Clarus 500 model) equipped with GC column (HP-1,30 m X $0.25 \mathrm{~mm} \mathrm{X} 0.25 \mu \mathrm{m})$. Sample injection tool place at the oven temperature of $50^{\circ} \mathrm{C}$ and was maintained at $50^{\circ} \mathrm{C}$ for I min, the temperature was increased up to $325^{\circ} \mathrm{C}$ at the heating rate of $10^{\circ} \mathrm{C} \mathrm{min}^{-1}$ and hold at $325^{\circ} \mathrm{C}$ for $2 \mathrm{~min}$.the GC-MS interface temperature was set to $250^{\circ} \mathrm{C}$ and helium was used as a carrier gas with a 
constant flow of $1.2 \mathrm{ml} / \mathrm{min}^{-1}$.NIST Library was use to identify the compounds representing peaks theGC spectrum.

\subsection{Flue Gas Analyses}

The flue Gas analyzer kid consists of probe, hand set remote connection, and analyzer. While running the Diesel Engine, with the help of an analyzer kid the emissions such as carbon monoxide $(\mathrm{CO})$, hydrocarbon $(\mathrm{HC})$, nitrogen oxides $(\mathrm{NOx})$, carbon dioxide $\left(\mathrm{CO}_{2}\right)$, and oxygen $\left(\mathrm{O}_{2}\right)$ for Biodiesel blends and Diesel fuel can be measured (Table 2).

\section{Result and Discussion}

The molar ratio of alcohol to oil, catalyst concentration, reaction temperature and time are the main factors affecting alkali-catalyzed esterfication. Of which, the molar ratio of alcohol to oil has a great effect on reducing FFA of vegetable oil. Molar ratios between 4.5:1 and 18:1 were reported in the literature [9-12].

Purification processes, including washing and drying, are necessary since untreated biodiesel contains impurities, such as free glycerol, soap, free fatty acid, methanol, catalysts, metals and glycerides. The remaining un reacted methanol in the biodiesel has safety risks and can corrode engine components, the residual catalyst (sodium hydroxide) can damage engine components, and soap in the biodiesel can reduce fuel lubricity and cause injector coking and other deposits [13].

Traditional water wash has been widely used and proved to be effective to remove most impurities. However, there are many disadvantages: production cost increase due to waste water treatment; Emulsion formation when treating biodiesel from waste cooking oil due to soap formation [14]; Methyl esters loss due to retention in the water phase. Dry washes, the use of ion exchange resin, such as magnesol, can remove all these disadvantages. However, Berros et al. [15] found only water washing has purified biodiesel, direct from glycerol separation, to the requirements of EN 14214 Standard. Therefore, in this study, both water and magnesol washes are applied. First use two $20 \%$ (v/v, based on methyl ester layer) water wash followed by $0.5 \%$ (wt/wt, based on methyl ester layer) magnesol wash.

The Heat of combustion refers to the measure of energy content in the fuel. Heating value of fuels is an important measure of its releasing energy for producing work. So the lower heating value of biodiesel is attributed to the decrease in engine power. The algal biodiesel was observed to record the highest calorific value of $44152 \mathrm{KJ} / \mathrm{Kg}$ apart from diesel, whilst the lowest calorific value of $34 \mathrm{MJ} / \mathrm{kg}$ was measured with respect to karanja. The energy content of oils depends on the place where they are grown, the season, composition and other factors. The calorific value of vegetable oils was observed to be lower than those of biodiesels. For methyl esters, the heat content increases as the length of the fatty acids chain increases. The presence of a significant amount of oxygen contributes to the lower energy content of biodiesel fuels.

Viscosity is a measure of the internal friction or resistance of oil to flow. As the temperature of oil is increased, its viscosity decreases and it is therefore able to flow more readily. Viscosity is the most important of biodiesel since it affects the operation of fuel injection equipment, particularly at low temperatures when the increase in viscosity affects the fluidity of the fuel. High viscosity leads to poorer atomization of the fuel spray and less accurate operation of the fuel injectors. The viscosity values of vegetable oils are between 27.84 and $52.76 \mathrm{~mm}^{2} / \mathrm{sec}$ at $40{ }^{\circ} \mathrm{C}$ whereas those of vegetable oils methyl esters are between 3.6 and $5.7 \mathrm{~mm} 2 / \mathrm{sec}$ Non edible oils were observed to have high viscosity values about six times more than ASTM limits. Algae were the most viscous with a viscosity of $9.1 \mathrm{~mm}^{2} / \mathrm{sec}$ 
at $40{ }^{\circ} \mathrm{C}$. The methyl esters and the blends were observed to have viscosity within the ASTM limits.

Density is another important property of biodiesel. It can be observed from the readings that babassu oil sample has the highest value of $0.946 \mathrm{~kg} / \mathrm{l}$ as compared to all other samples. The sun flower oils methyl ester has a minimum density value of $0.86 \mathrm{~kg} / \mathrm{l}$. The algae diesel fuel sample was observed to have a density value of $0.86 \mathrm{~kg} / 1$ which is lower than edible, non edible oils, methyl esters and its blends. The flash point of vegetable oil methyl esters is much lower than those of vegetable oils. The flash point of sun flower oil was observed to be highest $274{ }^{\circ} \mathrm{C}$ among methyl esters rape seed was observed to be lowest with $80{ }^{\circ} \mathrm{C}$. The flash and fire point of algae biodiesel was observed $52^{\circ} \mathrm{C}$ and $81^{\circ} \mathrm{C}$. Cloud and pour point respectively -30 to $-10^{\circ} \mathrm{C}$. The calculated molecular of weight biodiesel 744 . It is similar to GC-MS spectra results.

The ignition quality of a fuel can be deduced through its cetane number. A fuel with good ignition quality has a high cetane number, where the ignition delay period between the start of fuel injection and the onset of auto ignition is short. Cetane number of biodiesel varies with the feed stock used, but it is generally in the higher end of the typical diesel fuel range. The value of cetane number is found to generally increase with increasing carbon chain length. The cetane number of algae biodiesel was observed $44 \mathrm{KJ} / \mathrm{Kg}$.

Ultraviolet - visible (UV) spectroscopic analysis is rapid becoming a common technique for providing analytical data of biodiesel. In these results, the contribution of algal biodiesel component to overall absorption spectrum spectra of pure standard chemical of free fatty acids, methyl, ethyl esters and mono-, di-, triglycerides were measured. Since the all absorption of all components was below $450 \mathrm{~nm}$, one of those components contributed to characteristic maximum of the biodiesel absorption spectra in a visible range. pure aliphatic acids, esters, and glycerides are colorless substance and did not exhibit significant absorption in the visible range, natural fats and oils from plants and animal pigments exhibiting visible absorption. The absorption of vegetable oils in the visible regions is usually due to lipidsoluble pigments such as caroteniods and chlorophylls. Therefore a characteristic absorption of biodiesel in the visible range in Figure 1 is most likely caused by pigments and other pigments.

Characteristic shapes of biodiesel absorption spectra in visible range indicated that the information can be used to detect the biodiesel feedstock. Differences in position of absorption spectra gave the information about biodiesel level with regular diesel.

The volatile product can be found in the all spectrum of microalgal lipids extracts all collected extractions give band at 1014 and $3942 \mathrm{~cm}^{-1}$. An analysis of IR spectrum showed in Figure 2. The main composition stage, reveals the existence of the adsorption bands characteristic of these different bands.

$\mathrm{C}=\mathrm{O}$ carbonyl compound (aldehydes, acids, etc) are the strong $\mathrm{C}=\mathrm{O}$ stretching absorption bands in the region of 1870-1540 $\mathrm{cm}^{-1}$.If ester this band appears in the $1705 \mathrm{~cm}^{-1}$ and $1658 \mathrm{~cm}$ 1. C-O-C (Ethers), these stretching vibrations produce a strong band in the $1200-900 \mathrm{~cm}^{-1}$ region. $\mathrm{C}-\mathrm{H}$, adsorption bands as an example $2954 \mathrm{~cm}^{-1}, 2931 \mathrm{~cm}^{-1}$ and $2854 \mathrm{~cm}^{-1}$ correspond to the asymmetric and symmetric vibration modes of methyl group, ethylene groups respectively, $\mathrm{H}_{2} \mathrm{O}$ the adsorption bands of water can be between $1800-1200 \mathrm{~cm}^{-1}$. It referred to as oleaginous algae it has long been hypothesize that algae could be employed as s cell factors to produce oils and other lipids for biofuel and other materials.

Lipids are fatty acids and their derivatives as well as substance related biosynthetically or functionally ton these compounds. The most typical lipid classes of plant and animal origin consist of fatty acids linked by an ester bond to the trihydric alcohol, glycerol, or to other alcohols such as cholesterol, or by amide bonds to long chain bases, or on occasion to other 
amines. Lipid type is important to biodiesel production because the quality and variety of lipids will determine the need for pretreatment before it is converted to biodiesel, as well as the final fuel properties. It was graphically represented in Figure 3.

Gas chromatography is used to identify the chemical ingredients in the biodiesel. It was found Figure 3. and that there are different major esters in the algal oil methyl ester as shown Table 2. The chromatogram shows several compounds at various retention periods. Lipids (C9-C40) were identified using data base library.

The properties of biodiesel are also comparable with diesel properties. The trends of exhaust temperature and combustion efficiency of biodiesel are the same to diesel at different air- to fuel ratios. The $\mathrm{CO}, \mathrm{NO}, \mathrm{SO}_{2}$ and $\mathrm{CO}_{2}$ emissions of lower than diesel. Biodiesel results shows that the acceptable flue gas emission quality values.

\section{Conclusion}

Biodiesel an alternate diesel fuel is made from renewable biological sources such as algae oil by transesterification reaction using methanol. The purpose of the transesterification process is to lower the viscosity of the oil.

- This process is a potential alternative for the present industrial scale extraction Methods, particularly for algal oil extraction.

- Completely renewable sources of energy such as algae and ethanol were used to produce an 'ecofriendly' fuel.

- It can be concluded that the presence of biodiesel from green micro algae oil blended with petroleum diesel improves the parameter of cetane number.

- This is important since a high cetane number improves the quality of combustion and decreases NOx emission. Moreover causes less noise and greater durability of the engine.

- Spectroscopic study reveals very useful and rapid technique for characterization of biodiesel.

\section{Acknowledgement}

The authors wish to express the gratitude for the support and financial help given by Department of Science and Technology, New Delhi for their support under Net Work Programme of Bio-Alge Carbon Sequestration research under the title "Carbon Sequestration and cultivating algae for green bio-fuel Production".

\section{Reference}

[1] A.S. Abdulkareem, H. Uthman, A.S. Afolabi and O. L.Awonebe, "Sustainable Growth and Application in Renewable Energy Sources", InTech, (2011), pp. 243-268.

[2] M. Ahmmad, K. Ullah, M.A. Khan, M. Zafari, M. Tariq, S. Ali and S.Sultana, Energy Sources, Part A, (2011), pp. 1365-1374.

[3] D. Aghan, Progress in energy and combustion, vol. 31, (2005), pp. 406-487.

[4] A.K. Dalai and M.G. Kulkarni, Industrial \& Engineering Chemistry Research, vol. 45, (2006), pp. 2901-2913.

[5] J. Eaves and S.Eaves, Energy Policy. J., vol. 5, (2007), pp. 5958-5963.

[6] Z. Helwani, M.R. Othman, N.Aziz, W. J. N. Fernando and J. Kim, Fuel Processing Technology, vol. 90, (2009), pp. 1502-1514.

[7] S.M. El-Sabagh, S.T. Keera and A.R.Tama, Energy Source, vol. 33, (2011), pp. 401-409.

[8] T. Eevera, P. Balamurughan and S. Chittibabu, Energy Sources, PartA, vol. 33, (2011), pp. 1354-1364.

[9] C. Hamamci, A. Saydut, Y. Tonbul, C. Kaya and A.B. Kafadari, Energy Sources Part A, vol. 33, (2011), pp. 512-520.

[10] A.B. Hossain and A.N. Boyce, Agricultural Science, vol. 15, no. 4, (2009), pp. 312-317. 
[11] T. Khunrong, A. Punsuvon, P. Vaithanomisate and C. Pomchaitawand, Energy Sources, Part A, vol. 33, (2011), pp. 221-228.

[12] A.A. Refaat, S.T. El Sheltawy and K.U.Sadek, International Journal of Environmental Science and Technology, vol. 5, no. 3, (2008), pp. 315-322.

[13] R. Sarin, M. Sharma, S. Sinharay and R. K. Malhtra, Fuel, vol. 86, no. 10-11, (2006), pp. 1365-1371.

[14] S. Sathasivam and A. Manickam, "Biochemical Methods", revised $2^{\text {nd }}$ edition, new age international Pvt Ltd., (1996), pp. 23-25.

[15] H. Xu, X. Miao and Q. Wu., J. Biotechnlogy, vol. 125, (2006), pp. 499-507.

Table 1. Characterization of Biodiesel

\begin{tabular}{|c|c|c|c|c|}
\hline S. No & Property & Test Method & Limits ASTM D6751 & $\begin{array}{l}\text { Values of algae } \\
\text { Biodiesel }\end{array}$ \\
\hline 1 & $\mathrm{pH}$ & & $7-9$ & 7 \\
\hline 2 & Specific gravity & & $0.86-0.89$ & 0.86 \\
\hline 3 & Density & ASTM D 1298 & $7.1-7.4$ & 7.3 \\
\hline 4 & Flash point ${ }^{\circ} \mathrm{C}(\mathrm{F})$ & \multirow[b]{2}{*}{ D93 } & \multirow{2}{*}{$\begin{array}{l}100-170 \\
(212-338)\end{array}$} & 52 \\
\hline 5 & Fire point ${ }^{\circ} \mathrm{C}(\mathrm{F})$ & & & 81 \\
\hline 6 & Cloud point ${ }^{\circ} \mathrm{C}(\mathrm{F})$ & \multirow[t]{2}{*}{ ASTMD2500 } & -3 to 15 (26 to 59$)$ & -30 to -60 \\
\hline 7 & Pour point ${ }^{\circ} \mathrm{C}(\mathrm{F})$ & & -5 to $10(23$ to 50$)$ & -10 \\
\hline 8 & Viscosity $40 \mathrm{C} \mathrm{mm} 2 / \mathrm{s}$ & D445 & $1.9-6.0$ & 9.1 \\
\hline 9 & Cetane number & D613 & 47 min.(40-68) & 44. \\
\hline 10 & Acid value $\mathrm{mg} \mathrm{KOH} / \mathrm{g}$ & D664 & - & 1.9 \\
\hline 11 & Free fatty acid value & & - & 0.9 \\
\hline 12 & Saponification value & & - & 192 \\
\hline 13 & Calorific value $\mathrm{KJ} / \mathrm{Kg}$ & ASTM D240 & & 44152 \\
\hline 14 & Moisture content $\%$ & & 0.050 max. & 0.001 \\
\hline 15 & Carbon residue \%, & D524 & 0.050 max. & 0.008 \\
\hline 16 & $\mathrm{Na}, \mathrm{ppm}$ & EN14538 & 5 max. & 1.6 \\
\hline 17 & $\mathrm{~K}, \mathrm{ppm}$ & & $5 \max$. & 2.1 \\
\hline 18 & Water sedimentation $\%$, & D2709 & 0.050 max. & 0.001 \\
\hline 19 & $\begin{array}{l}\text { Cupper corrosion test } 2 \mathrm{~h} \\
@ 50^{\circ} \mathrm{C} \text {, }\end{array}$ & ASTM-D445 & No. 3 & No. $2 b$ \\
\hline 20 & Ash content mass \%, & D482 & 0.0001 & nil \\
\hline
\end{tabular}

Table 2. Flue Gas Analysis Result for Biodiesel

\begin{tabular}{|c|c|c|c|c|}
\hline S.No & Parameter & Range & Diesel & Biodiesel \\
\hline 1 & $\mathrm{NO}$ & $0-5000 \mathrm{ppm}$ & \pm 5 & .0006 \\
\hline 2 & $\mathrm{CO}$ & $0-10000 \mathrm{ppm}$ & 1 & 1.5 \\
\hline 3 & $\mathrm{O}_{2}$ & 0 to $25 \%$ & 5 & 2.2 \\
\hline 4 & $\mathrm{SO}_{2}$ & $0-5000 \mathrm{ppm}$ & \pm 5 & 3 \\
\hline 5 & $\mathrm{CO}_{2}$ & $0-$ fuel Value $\%$ & 0.9 & 0.2 \\
\hline 6 & $\mathrm{NO}_{2}$ & $0-5000 \mathrm{ppm}$ & - & Nil \\
\hline
\end{tabular}


Table 3. GC-MS Spectra Result for Biodiesel

\begin{tabular}{|l|l|l|l|}
\hline S.No & Peak & Name & $\begin{array}{l}\text { Molecular } \\
\text { weight }\end{array}$ \\
\hline 1 & C8 & Octanoic acid & 130 \\
\hline 2 & C10 & Decanoic acid & 154 \\
\hline 3 & C10 & Dodecanoic acid & 186 \\
\hline 4 & C11 & 2H-1Benzopyran 2-on & 174 \\
\hline 5 & C12 & Dodecanoic acid & 196 \\
\hline 6 & C13 & Octadecane - Biodiesel & 254 \\
\hline 7 & C14 & Marist oleic acid & 222 \\
\hline 8 & C14 & Hexenoic acid & 238 \\
\hline 9 & C16 & Hexadecadienoic acid & 251 \\
\hline 10 & C16 & Palmitoliec acid & 252 \\
\hline 11 & C17 & Styrene & 230 \\
\hline 12 & C20 & Eicosadienoic acid & 292 \\
\hline 13 & C21 & Pentadecene & 296 \\
\hline 14 & C21 & Butanoic acid & 386 \\
\hline 15 & C21 & Heneicosane & 296 \\
\hline 16 & C23 & Docosahexanoic acid & 382 \\
\hline 17 & C24 & Nerronic acid & 416 \\
\hline 18 & C25 & Pentacosane & 352 \\
\hline 19 & C26 & Hexacosane & 366 \\
\hline 20 & C32 & Dotriacontane & 450 \\
\hline 21 & C44 & Tetracontane & 618 \\
\hline & & & \\
\hline
\end{tabular}

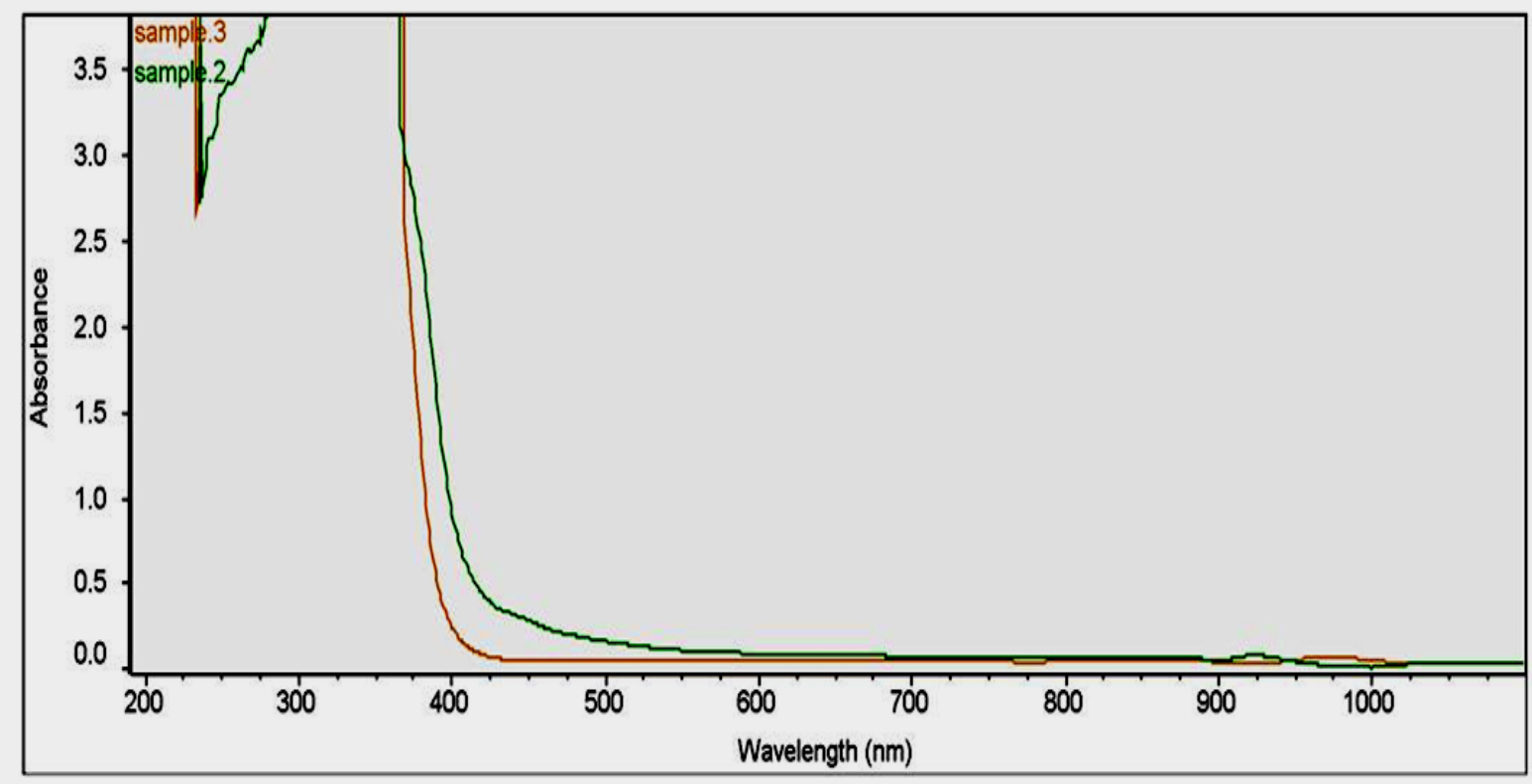

Figure 1. UV -Visible Spectra for Diesel and Biodiesel 


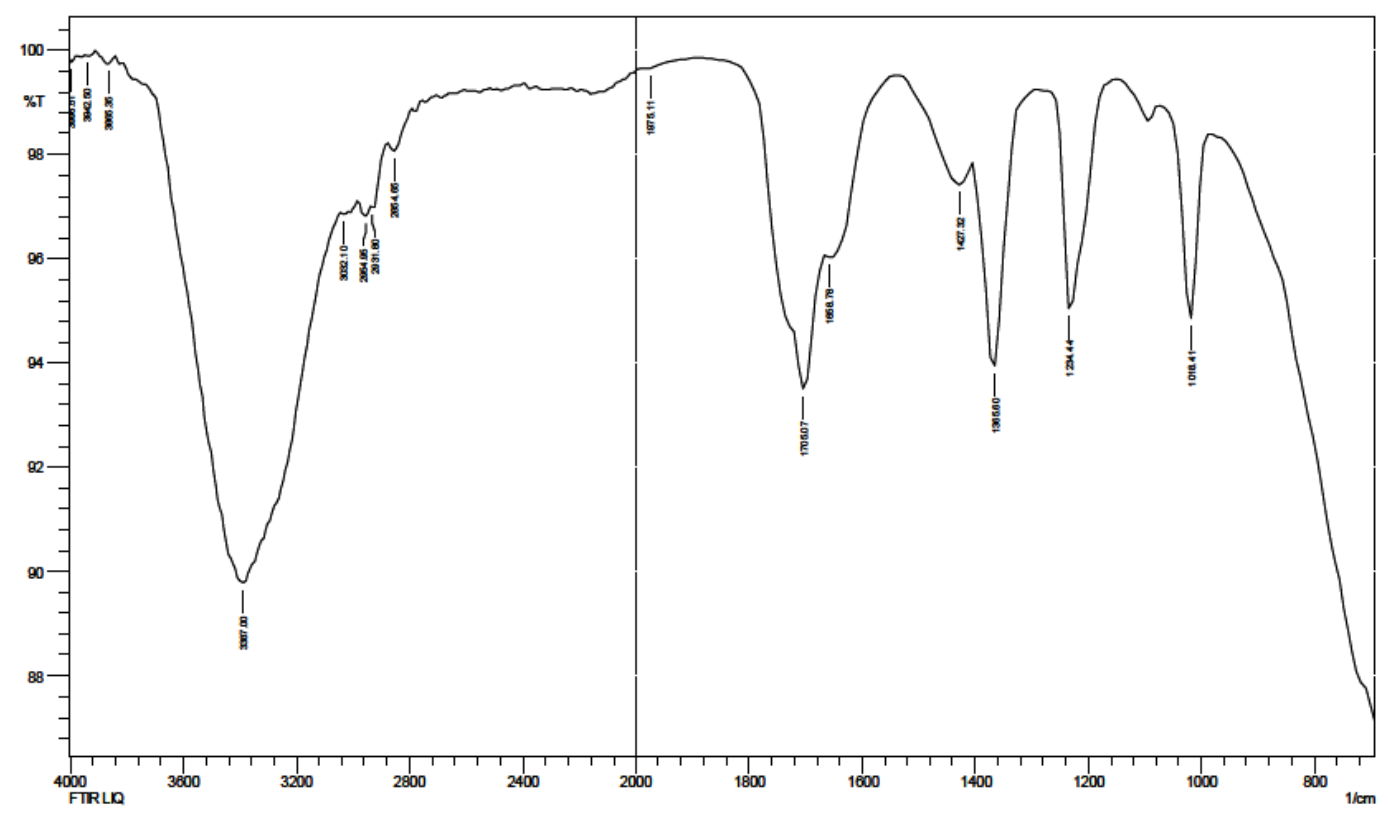

Figure 2. FTIR Spectra for Algal Biodiesel

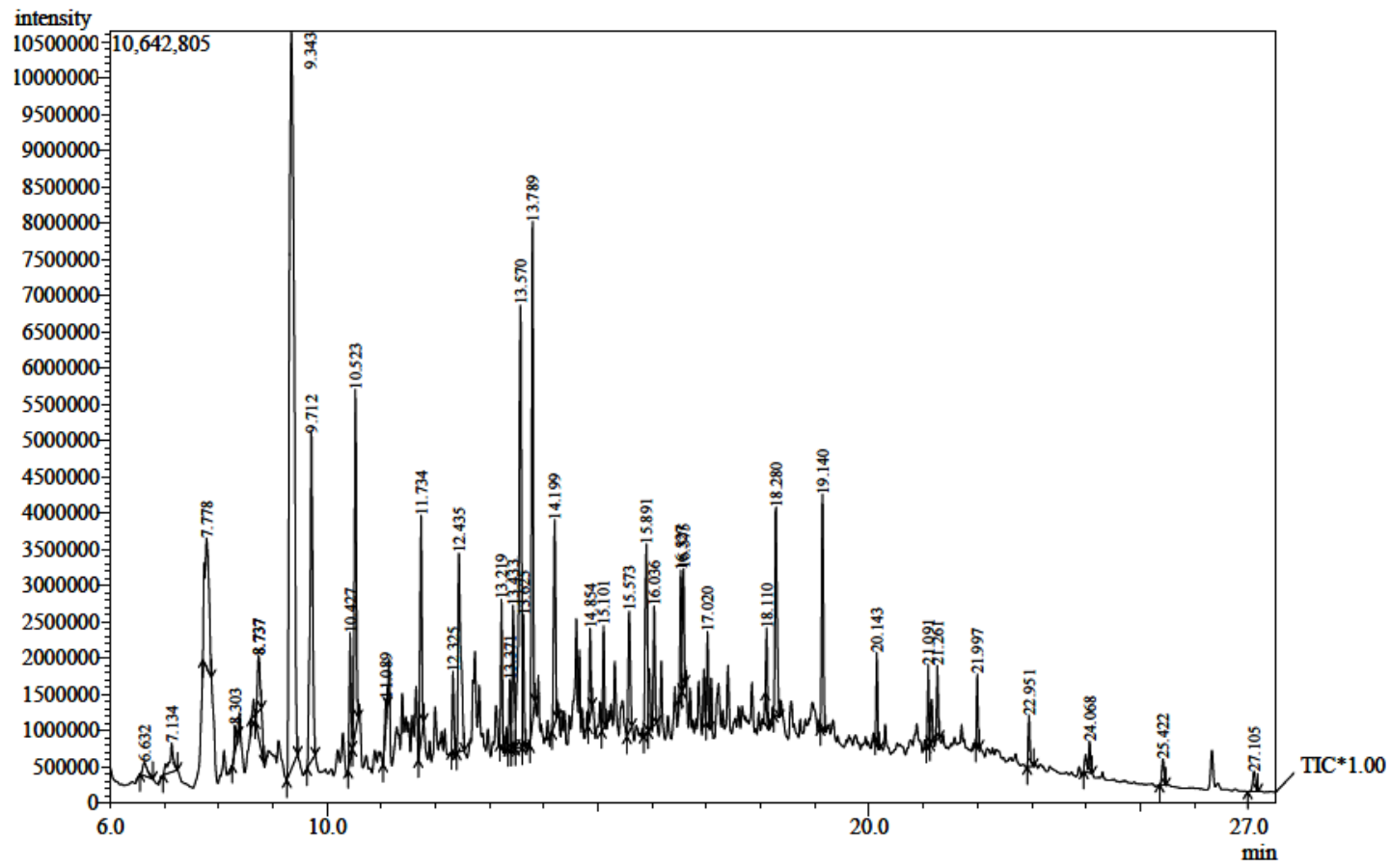

Figure 3. GC-MS Spectra for Algal Biodiesel 
International Journal of Bio-Science and Bio-Technology Vol.6, No.5 (2014) 